\title{
Article
}

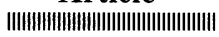

\section{Using an Imaging Plate to Measure the Concentration of Radon Progeny in Air}

\author{
Takeshi IImoto, Katsuhiko KAwASHIMA ${ }^{* \dagger}$ and Toshiso KosAKo \\ Research Center for Nuclear Science and Technology, The University of Tokyo \\ 2-11-16 Yayoi, Bunkyo-ku, Tokyo 113-0032, Japan \\ * Science University of Tokyo \\ 1-3 Kagurazaka, Shinjuku-ku, Tokyo 162-8601, Japan \\ Received May 10, 2004
}

\begin{abstract}
A simple technique was developed for using an imaging plate (IP) to estimate the individual concentrations of radon progeny in the air. The objective of this technique is to survey concentrations in high-humidity environments, such as caves, utility mains, and underground facilities.

An IP called BAS-III, which performs well in extremely humid environments, was selected. The sampling flow rate was 65 liters per minute by a $47 \mathrm{~mm}$-dia. glass-fiber filter (GF/F), and the grab sampling time was determined to be 5-10 minutes. One minute after the air sampling, the surface of the filter was attached directly to the IP in a prepared cassette. This was repeated six times for 10 minutes, for a total exposure of 60 minutes. Six values of Photo-Stimulated Luminescence (PSL) indicating the decay curve of the radon progeny sampled on the filter were analyzed. In environments with extremely high concentrations of radon, more accurate measurements can be obtained by making a simple distinction between PSL values for $\alpha$ and $\beta$ rays. The lower detection limit for the equilibrium equivalent concentration (EEC) of radon was estimated to be about $20 \mathrm{Bqm}^{-3}$. This system can be successfully adopted in humid areas.
\end{abstract}

Key Words : imaging plate, radon progeny concentration, high-humidity environment

\section{Introduction}

The airborne ${ }^{222} \mathrm{Rn}$ (radon) family is a major natural radioactive source generating an effective dose. This family is responsible for about one half of the personal effective dose due to natural radiation. The important target isotopes in the radon family are decay products referred to as radon progeny, which are fine airborne particles with short half-lives. Specifi-

${ }^{\dagger}$ Present address : Tokyo Electric Power Company, Fukushima Daini Nuclear Power Station, 12, Kohamasaku, Namikura, Naraha-cho, Futaba-gun, Fukushima Pref. 979-0695, Japan. cally, they are ${ }^{218} \mathrm{Po},{ }^{214} \mathrm{~Pb},{ }^{214} \mathrm{Bi}$, and ${ }^{214} \mathrm{Po}$. Therefore, it is important to estimate the airborne concentration of radon progeny.

At present, radon progeny in unique environments such as caves, utility mains, and underground facilities are often surveyed. These environments have a naturally enhanced radiation level; thus, investigation of the effective dose is needed. Actually, there are a large number of commercial instruments for measuring radon progeny concentrations. However, most of them are too large and cumbersome for use in these unique environments. In addition, commercial instruments are mechanically affected by humidity in the air, which could reach $100 \%$ 
in these unique environments.

Since a new system with the potential to overcome these problems would be of value, we are proposing the new method demonstrated here. This method uses an imaging plate as a radiation detector for estimating the airborne concentration of individual radon progeny.

\section{Materials and Methods}

$2 \cdot 1$ Imaging plate

An imaging plate (IP) is a relatively new and simple tool as a two-dimensional radiation detector. In this study, the BAS- III * developed by the Fuji Photo Film Co., Ltd., was selected. This IP shows high detection sensitivity for $\alpha$ particles and high detection stability in environments with varying degrees of humidity. $\left({ }^{*}\right.$ Recently, BAS-MS was newly developed in place of BAS-III. The sensitivity of BAS-MS is almost the same as that of BAS-III or slightly better.)

For an analysis based on the IP measurement, a special quantitative unit of PhotoStimulated Luminescence (PSL) is used. This unit indicates the level of radiation exposed. The value "100 PLS $\mathrm{mm}^{-2}$ " is defined to be equivalent to the detection value gained after exposure by X-rays of $0.15 \mathrm{mR}$ with the $\mathrm{W}$ target. The PSL is approximately proportional to the product of the source activity on the surface of the IP and the exposure time. The proportional factor is changed by both the type and energy of the radiation exposed. Radon short-lived progeny consisting of four isotopes emits $\alpha, \beta$, and $\gamma$ rays with a wide range of energy. According to our tests, the ratio of sensitivity (PSL $\mathrm{mm}^{-2}$ per exposure of single radiation particle) on BAS- III is approximately $\alpha$ : $\beta: \gamma_{\mathrm{L}}: \gamma_{\mathrm{H}}=50: 10: 1: 0.1$. Here, $\gamma_{\mathrm{L}}$ means low- energy $\gamma$ rays and $\gamma_{\mathrm{H}}$ is high-energy $\gamma$ rays. In these tests, the following radiation sources are used : the $\alpha$ source is ${ }^{241} \mathrm{Am}(5.49 \mathrm{MeV})$, the $\beta$ source is ${ }^{32} \mathrm{P}(1.71 \mathrm{MeV})$, the low-energy $\gamma$ source is ${ }^{241} \mathrm{Am}(60 \mathrm{keV})$, and the high-energy $\gamma$ source is ${ }^{60} \mathrm{Co}$ ( 1.17 and $1.33 \mathrm{MeV}$ ). The result is quite similar to that reported by Mori ${ }^{1}$. The gamma sensitivity was negligible for the purpose of our study when compared with that to $\alpha$ and $\beta$ rays. Therefore, we decided to disregard the PSL value generated by $\gamma$ rays in the measurements.

For the use of IP, it is important to investigate the PSL fading feature. Related information has been reported by Ohuchi ${ }^{2}$, who has demonstrated that environmental temperatures change the fading speed. In this study, however, it is assumed that the IP would be used in a comparatively stable environment under a temperature of $15-25{ }^{\circ} \mathrm{C}$. Therefore, the fading speed is assumed to be constant.

PSL fading curve has been investigated using $\alpha$ rays of ${ }^{241} \mathrm{Am}, \beta$ rays of ${ }^{32} \mathrm{P}$, and $\gamma$ rays of ${ }^{241} \mathrm{Am}$. The results of the fading tests are shown in Fig.1. According to Fig.1, the first quick fading phenomenon finishes after about 10 hours from the end of the exposure in all types of radiation. After about 10 hours, the fading speed decreases. In this study, the standard time-point for analyzing PSL was determined to be after 24 hours from the end of the exposure.

We used the BAS-1800 system as the PSL analyzer. This system was operated under the following four scanning parameters throughout the research : sensitivity $=\mathrm{S} 4000$, latitude $=\mathrm{L} 4$, gradation $=256$, and resolution $=100 \mu \mathrm{m}$. The definitions of these parameters are explained in the Appendix. 


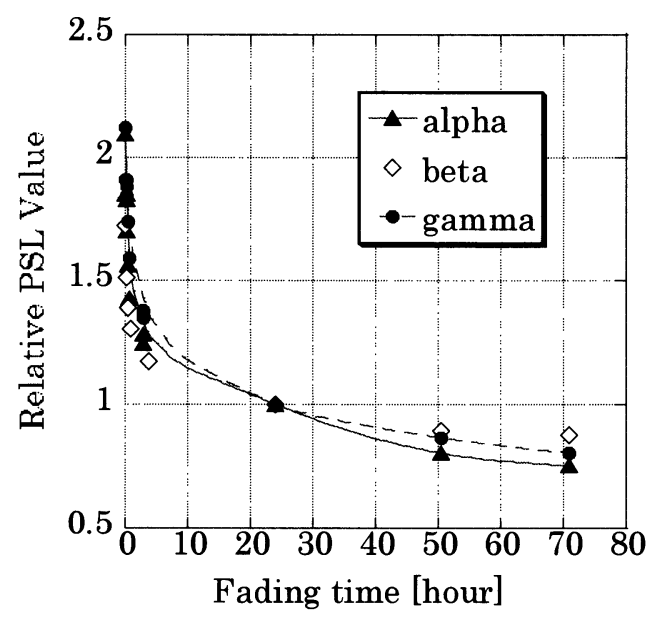

Fig. 1 Results of fading tests for IP BAS-III. PSL fading curves were examined using ${ }^{241} \mathrm{Am}$ for $\alpha$ ray, ${ }^{32} \mathrm{P}$ for $\beta$ rays, and ${ }^{241} \mathrm{Am}$ for $\gamma$ rays.

$2 \cdot 2$ Measuring technique for determining the concentration of individual radon progeny

Individual concentrations of radon progeny were measured using a combination of a "filter method" and "grab-sampling and decay $\operatorname{method}^{3) "}$.

A glass-fiber filter ( $\mathrm{GF} / \mathrm{F}$, manufactured by the Whatman Co.) was selected for the sampling filter. The pore size of the filter was equivalent to $0.8 \mu \mathrm{m}$. The collection efficiency for the radon progeny was around $100 \%$, and the pressure drop during air sampling was lower than that of other similar filters ${ }^{4}$. A sampling flow rate was 65 liters per minute, and the grab-sampling time was 5-10 minutes. One minute after the air sampling, the surface of the filter holding the radon progeny was attached directly to the IP' $s$ detection surface inside an IP cassette. The exposure was repeated six times for 10 minutes each on the different position of IP for a total exposure of 60 minutes. This procedure is shown in Table 1 .

The PSL values from the six exposures were analyzed to calculate the concentration of radon progeny using a least squares method. The basic equation is

$$
\begin{aligned}
& P_{\mathrm{a}+\mathrm{b}} K_{\mathrm{a}}=K_{\mathrm{f}} V\left[\eta_{\mathrm{a}} I_{\mathrm{aa}}(\mathrm{i})+\eta_{\mathrm{c}} I_{\mathrm{ac}}(\mathrm{i}) X_{\mathrm{a}}+\eta_{\mathrm{c}} I_{\mathrm{bc}}\right. \\
& \text { (i) } \left.X_{\mathrm{b}}+\eta_{\mathrm{c}} I_{\mathrm{cc}}(\mathrm{i}) X_{\mathrm{c}}\right]
\end{aligned}
$$

The adjunctive characters of $a, b$, and $c$ mean ${ }^{\circ} \mathrm{a}={ }^{218} \mathrm{Po}, \mathrm{b}={ }^{214} \mathrm{~Pb}$, and $\mathrm{c}={ }^{214} \mathrm{Bi}\left(={ }^{214} \mathrm{Po}\right)$ ".

$P_{\mathrm{a}+\mathrm{b}}\left[\mathrm{PSL} \mathrm{mm}^{-2}\right]=$ PSL value generated by both $\alpha$ and $\beta$ rays after 24 hours from the end of the exposure.

$K_{\mathrm{a}}=$ Correction factor for the PLS value changing into the value influenced only by $\alpha$ rays from radon progeny. The concentration of radon progeny was basically calculated using the PSL value generated by $\alpha$ rays.

$K_{\mathrm{f}}=$ Correction factor for the fading feature standardized after 24 hours from the end of the exposure.

$V\left[\mathrm{~m}^{3} \mathrm{sec}^{-1}\right]=$ Sampling flow rate.

$\eta_{\mathrm{a}}, \eta_{\mathrm{c}}\left[\mathrm{PSL} \mathrm{mm}^{-2}\right.$ decay $\left.^{-1}\right]=$ Conversion factors from the $\alpha$ decay number on the filter during the exposure time to the PSL value gen-

Table 1 Time sequence for sampling radon progeny and exposing them to IP ( $\mathrm{min}$ )

\begin{tabular}{llllllll}
\hline \multirow{2}{*}{$\begin{array}{l}\text { Sampling } \\
\text { progeny }\end{array}$} & Preparing & \multicolumn{6}{l}{ Exposing IP to sampling filter } \\
\cline { 2 - 8 } & Ist & 2nd & 3rd & 4th & 5th & 6th \\
\hline $0-10^{*}$ & $10-11$ & $11-21$ & $21-31$ & $31-41$ & $41-51$ & $51-61$ & $61-71$ \\
\hline
\end{tabular}

*Example of sampling time: $10 \mathrm{~min}$ 


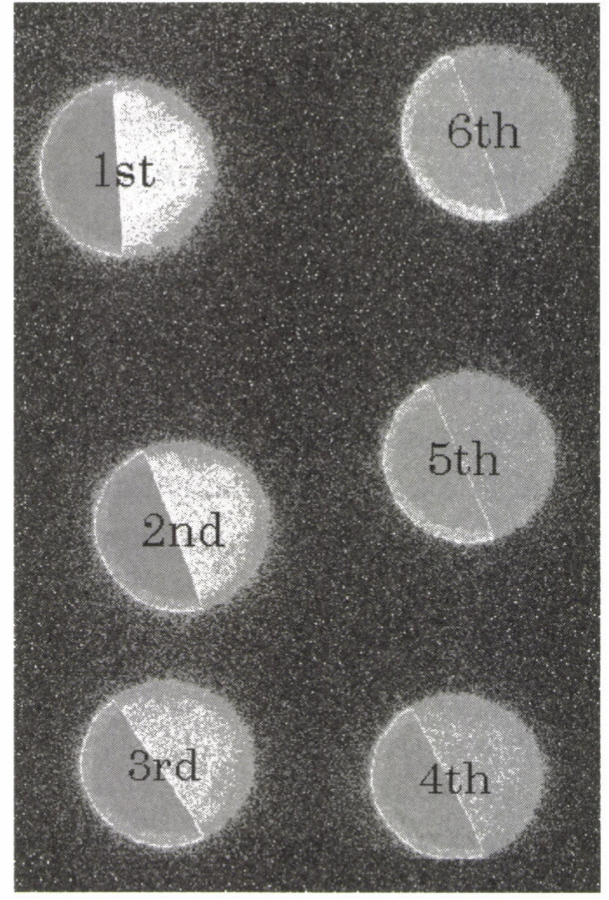

Fig. 2 Distinguished measurement between $\alpha$ and $\beta$ rays.

The left half of each PSL-image is the $\alpha$ and $\beta$ region $(\mathrm{a}+\mathrm{b})$, which is the bare IP part. The right half is the $\beta$ region(b), which is covered with two sheets of paper in order to shield the $\alpha$ rays.

erated by the $\alpha$ rays.

$I_{\mathrm{nm}}(\mathrm{i})[$ decay $]=$ Decay number as an 'm' isotope in the $i^{\text {th }}\left(=1^{\text {st }}-6^{\text {th }}\right)$ exposure time for an ' $\mathrm{n}$ ' isotope collected during the sampling time under the condition where flow rate $=1\left[\mathrm{~m}^{3}\right.$ $\left.\mathrm{sec}^{-1}\right]$ and $X_{\mathrm{j}}=1\left[\mathrm{~Bq} \mathrm{~m}^{-3}\right]$

$X_{\mathrm{j}}\left[\mathrm{Bq} \mathrm{m}{ }^{-3}\right]=$ Concentration of radon progeny

Six equations can be obtained from the PSL values based on the six exposures. The correction factor $K_{\mathrm{a}}$ and conversion factors $\eta_{\mathrm{a}}$ and $\eta_{\mathrm{c}}$ in the basic equation(1) are discussed in the next section.

When the concentration of radon progeny in the target environment is high, the following procedure can be used to reduce the estimation errors. In order to discriminate PLS values between $\alpha$ and $\beta$ rays, one half of the filter surface was covered with two sheets of paper during exposure to shield the $\alpha$ rays. The paper was standard copy paper with a thickness of about $90 \mu \mathrm{m}$ per sheet. With this procedure, the PSL value originating only from the $\alpha$ rays could be more easily and accurately estimated than with the use of the correction factor $K_{\mathrm{a}}$ :

$$
P_{\mathrm{a}+\mathrm{b}} K_{\mathrm{a}}=P_{\mathrm{a}+\mathrm{b}}-P_{\mathrm{b}}
$$

$P_{\mathrm{a}+\mathrm{b}}, P_{\mathrm{b}}\left[\right.$ PSL $\left.\mathrm{mm}^{-2}\right]=$ PSL values of the bare IP region $(\mathrm{a}+\mathrm{b})$ or $\beta$ region (b) covered with two sheets of paper corrected after 24 hours from the end of the exposure.

A visual example of measurements discriminating between $\alpha$ and $\beta$ rays is shown in Fig.2. The left half of each PSL-image is the $\alpha$ and $\beta$ region $(a+b)$, which is the bare IP part. The right half is the $\beta$ region (b), which is covered with two sheets of paper in order to shield the $\alpha$ rays.

\section{Discussion}

$3 \cdot 1 \quad$ Correction factor of $K_{\mathrm{a}}$

The correction factor $K_{\text {a }}$ was determined as the average value of $\left(P_{\mathrm{a}+\mathrm{b}}-P_{\mathrm{b}}\right) / P_{\mathrm{a}+\mathrm{b}}$ based on 20 experiments on the basis of the $\alpha / \beta$-discrimination in high-concentration environments. For these experiments, the individual concentration ratio among radon progeny was artificially changed in a large range by varying the environmental conditions, especially the aerosol concentration in the air. In fact, the individual ratio was changed here between approximately ${ }^{218} \mathrm{Po}:{ }^{214} \mathrm{~Pb}:{ }^{214} \mathrm{Bi}\left(={ }^{214} \mathrm{Po}\right)=1: 1: 1 \mathrm{in}$ 
an equilibrium condition and $1: 0.4: 0.2$ in a special condition. As a result, $K_{\mathrm{a}}=0.87$ was obtained as the average value. The range of its error was about $10 \%$. We believe that the value of $K_{\mathrm{a}}$ estimated here can be used only in a low-concentration environment because the other errors would be larger than that of $K_{\mathrm{a}}$.

\section{$3 \cdot 2$ Conversion factor}

The conversion factors for ${ }^{218} \mathrm{Po}$ and ${ }^{214} \mathrm{Po}$ based on the $\alpha$ decay number to the PSL value of $P_{\mathrm{a}+\mathrm{b}}\left(\eta_{\mathrm{a}}\right.$ and $\eta_{\mathrm{c}}$, respectively $)$ are determined by the following comparison experiment with a $\mathrm{Si}$ semiconductor detector. These conversion factors include the detection efficiency.

A GF/F filter holding the radon progeny on its surface was prepared. After attaching the filter to the IP surface by inserting two papers on one half for 5 minutes, the $\alpha$ spectrum using a $\mathrm{Si}$ semiconductor detector was measured for 5 minutes. This alternate measurement method using an IP and a Si detector was repeated 7 times at 30 -seconds intervals. The concentrations of the radon progeny sampled on the source filter were calculated by the least squares method ${ }^{5)}$ using the $\alpha$ decay curve obtained by the Si detector. The individual concentrations were substituted for 7 equations (1) and (2) as well as the PSL values generated by only $\alpha$ rays. Then, the two unknown factors of $\eta_{\mathrm{a}}$ and $\eta_{\mathrm{c}}$ were determined by the least squares calculation. This experiment was performed 10 times to estimate the average value. As a result, the values of $\eta_{\mathrm{a}}=7.4 \times 10^{-5}$ and $\eta_{\mathrm{c}}$ $=1.3 \times 10^{-4}$ were obtained. These values have a range of error of $5 \%$ each.

\subsection{Detection sensitivity}

The background PSL generated by natural radiation during the IP storage period is a main decision factor contributing to the detection sensitivity. Here, the following three representative methods for storing the IP during the 24hour fading period are discussed. The first method involves the use of a commercial IP cassette (cassette storage). Its natural environment background is $70-80 \mu \mathrm{Sv}$ per hour. The second method involves placing the IP in a $5 \mathrm{~cm}$-thick lead shield (cassette $+\mathrm{Pb}(5 \mathrm{~cm})$ storage). The background is estimated to be $10-$ $15 \mu \mathrm{Sv}$ per hour. The third involves placing the IP in a cassette with a $25 \mathrm{~cm}$-thick iron shield (cassette $+\mathrm{Fe}(25 \mathrm{~cm})$ storage $)$. The background is estimated to be about $5-7 \mu \mathrm{Sv}$ per hour. We obtained the following equations to estimate the background PSL depending on the storage duration.

$$
\begin{aligned}
& \text { Cassette storage : } P=0.17 \mathrm{H} \\
& \text { Cassette }+\mathrm{Pb}(5 \mathrm{~cm}) \text { storage : } P=0.038 \mathrm{H} \\
& \text { Cassette }+\mathrm{Fe}(25 \mathrm{~cm}) \text { storage : } P=0.022 \mathrm{H} \\
& P\left[\text { PSL } \mathrm{mm}^{-2}\right]=\text { Background PSL value } \\
& \mathrm{H}[\text { hours }]=\text { Storage duration under each con- } \\
& \text { dition }
\end{aligned}
$$

A lower detection limit for the IP system was estimated under these conditions: (1) the cassette $+\mathrm{Pb}(5 \mathrm{~cm})$ storage method is adopted; (2) the fading time is 24 hours; and (3) the net PSL value must be at least two times the background PSL. Then, the lower detection limit of the equilibrium equivalent concentration of radon (EEC Rn) using this system was calculated to be about $20 \mathrm{Bqm}^{-3}$.

This detection limit is not better than other representative $\alpha$ detectors, such as the $\mathrm{Si}$ semiconductor detector or the $\mathrm{ZnS}(\mathrm{Ag})$ scintillation detector. In fact, a $\mathrm{Si}$ detector $(50 \mathrm{~mm}$ dia.) will accomplish the detection limit of $2-3$ 
$\mathrm{Bqm}^{-3}$, and a $\mathrm{ZnS}(\mathrm{Ag})$ detector (50 mm dia.) will accomplish the detection limit of 4-7 $\mathrm{Bqm}^{-3}$. However, the purpose of this study must be emphasized once again. This IP measurement system was developed for use in extremely humid environments in place of existing methods. The detection limit of the IP system is sufficient for our purpose to estimate radon progeny concentration in unique environments, such as underground areas.

\subsection{More sensitive technique with IP}

One of the advantages of IP is its high resolution up to the range of a few tens of $\mu \mathrm{m}$. Using this feature effectively, an $\alpha$ particle can be discriminated from other types of radiation because the size of the spots generated by $\alpha$ particles is clearly different from that of the $\beta$ or $\gamma$ rays. Adapting this procedure would result in a more sensitive measurement. For example, Furuichi and lida have applied this technique to the measurement of the size distribution of radon progeny ${ }^{6}$. Their technique requires more complex preparation, but it includes a great potential. The method for measuring radon progeny with IP is still being developed.

\section{$3 \cdot 5$ Example data}

Some example data measured by this IP system are indicated in Table 2.

ID No.1-1 and No.1-2 show the results of comparison tests in a radon chamber with the $\mathrm{ZnS}(\mathrm{Ag})$ scintillation method. For reliable measurements by the $\mathrm{ZnS}(\mathrm{Ag})$ instrument, the humidity in a radon test chamber was controlled around $70 \%$ under $20^{\circ} \mathrm{C}$. According to these data, individual radon progeny concentrations of ${ }^{214} \mathrm{~Pb}$ and ${ }^{214} \mathrm{Bi}$ were adequately estimated.

ID No.2 is an example of data obtained from the inside of a natural cave located at Ikoji Temple in Tokyo. ID No.3 is the natural radon data obtained from a bathroom at the Masutomi spa in Yamanashi Prefecture. Actually, both measurements of the cave and spa were performed in environments with high humidity up to $100 \%$. The IP system can be fully applied in these unique environments.

\section{Conclusion}

A simple and new technique for estimating the concentration of individual radon progeny has been developed.

This method uses an imaging plate(IP) of BAS-III as a radiation detector. Its detection

Table 2 Example data estimated by IP measuring system

\begin{tabular}{|c|c|c|c|c|c|c|}
\hline $\begin{array}{l}\text { ID } \\
\text { No. }\end{array}$ & Target & Humidity & ${ }^{214} \mathrm{~Pb}$ & $\begin{array}{l}{ }^{214} \mathrm{Bi} \\
{\left[\mathrm{Bqm}^{-3}\right.}\end{array}$ & EEC Rn* & Remarks \\
\hline $1-1$ & \multirow{2}{*}{$\mathrm{RTC}^{* *}$} & \multirow{2}{*}{$70 \%$} & $\begin{array}{l}1820 \\
1870\end{array}$ & $\begin{array}{l}1590 \\
1440\end{array}$ & $\begin{array}{l}1740 \\
1780\end{array}$ & $\begin{array}{c}\mathrm{ZnS}(\mathrm{Ag}) \\
\text { IP }\end{array}$ \\
\hline $1-2$ & & & $\begin{array}{l}2260 \\
2370\end{array}$ & $\begin{array}{l}1950 \\
1920\end{array}$ & $\begin{array}{l}2180 \\
1920\end{array}$ & $\begin{array}{c}\mathrm{ZnS}(\mathrm{Ag}) \\
\mathrm{IP}\end{array}$ \\
\hline $\begin{array}{l}2 \\
3\end{array}$ & $\begin{array}{c}\text { Cave } \\
\text { Rn spa }\end{array}$ & $\begin{array}{l}95-100 \% \\
95-100 \%\end{array}$ & $\begin{array}{l}235 \\
460\end{array}$ & $\begin{array}{l}182 \\
380\end{array}$ & $\begin{array}{l}217 \\
435\end{array}$ & IP \\
\hline
\end{tabular}

ID No.1-1 and 1-2 are results of comparison tests between $\mathrm{ZnS}(\mathrm{Ag})$ scintillation detector and IP method. The range of estimation errors for all is less than $10 \%$. *EEC Rn = Equilibrium Equivalent Concentration of Radon

${ }^{* *} \mathrm{RTC}=$ Radon Test Chamber 
limit is about $20 \mathrm{Bqm}^{-3}$ as the equilibrium equivalent concentration of radon. This level is sufficient for natural environments, such as caves, utility mains, and underground facilities. A remarkably advantage of this system is that measurements are possible in very humid environments up to $100 \%$.

\section{Appendix}

The followings are the definitions of the scanning parameters for the PSL analyzing system. They are derived from the instruction manual of the BAS- 1800 .

\section{1) Sensitivity}

; refers to the range of PSL $\mathrm{mm}^{-2}$, at which the PSL analyzing system can measure. The center value of this range is in inverse proportion to the sensitivity. The indication is as S400, S100, S4000, or S10000, etc. The definition of "Sensitivity" of an IP is very similar to that of the sensitivity of photo-film.

\section{2) Latitude}

; refers to the decision quantity for the width of a range of PSL $\mathrm{mm}^{-2}$, at which the PSL analyzing system can measure. This value is an exponential index. The indication is as L1, $\mathrm{L} 2$, or L4, etc.

The relationship between sensitivity and latitude is shown in Fig.3.

\section{3) Gradation}

; refers to the division number used for indicating the PSL $\mathrm{mm}^{-2}$ values. The indication is as 256,1024 , or 4096 , etc.

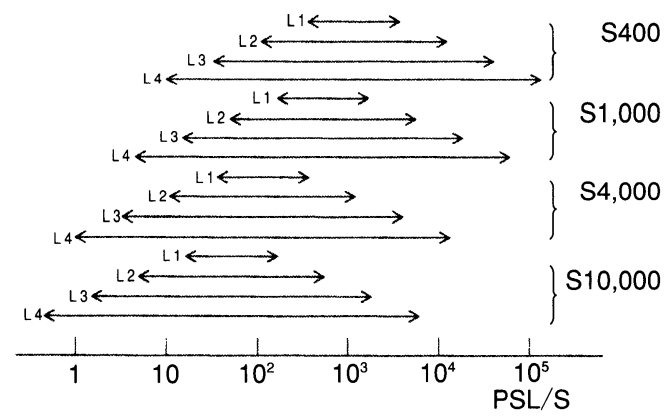

Fig. 3 Relationship between sensitivity and latitude.

\section{4) Resolution}

; refers to the smallest unit of pixel size for analyzing information and drawing imaging data, such as $50 \mu \mathrm{m} \times 50 \mu \mathrm{m}, 100 \mu \mathrm{m} \times 100 \mu \mathrm{m}$, $200 \mu \mathrm{m} \times 200 \mu \mathrm{m}$, etc.

\section{References}

1) Mori, C. and Matsumura, A., Radioactivity and geometrical distribution measurements of alphaemitter specimens with an imaging plate, $\mathrm{Nucl}$. Instrum. Meth. Phys. Res., A312, 39-42 (1992)

2) Ohuchi, H., Yamadera, A. and Nakamura, T., Functional equation for the fading correction of imaging plates, Nucl. Instrum. Meth. Phys. Res., A 450, 343-352 (2000)

3) Thomas, J. W., Measurement of radon daughters in air, Health Phys., 23, 783-789 (1972)

4) Iimoto, T., Characteristics of major filters used for Rn-222 progeny measurements, Radiat. Meas., 29 (2), 161-164 (1998)

5) Martz, D. A., Holleman, D. F., McCurdy, D. E. and Schiage, K. J., Analysis of atmospheric concentration of $\mathrm{RaA}, \mathrm{RaB}$, and $\mathrm{RaC}$ by alpha spectroscopy, Health Phys., 17, 131-138 (1969)

6) Furuichi, S. and Iida, T., Measurement of size distribution of radon and thoron progeny aerosols using an imaging plate, IN : Abstracts of the $37^{\text {th }}$ Japan Health Physics Society Conference, A-8, 8 (2003) (in Japanese) 
要旨

\title{
空気中ラドン子孫核種䝶度測定におけるイメージングプレートの適用
}

\author{
飯本武志，川島克彦*, ，小佐古敏荘 \\ 東京大学原子力研究総合センター \\ 113-0032 東京都文京区弥生 2-11-16 \\ *東京理科大学 \\ 162-8601 東京都新宿区神楽坂 1-3
}

イメージングプレート (IP)を用いて空気中のラドン子孫核種濃度 $(\mathrm{RP})$ を評価する手法を検討し た。 $47 \mathrm{~mm}$ 径ガラス䄉維フィルタで $\mathrm{RP}$ を 10 分間採取 (流速毎分約 $65 \mathrm{~L}$ ), 捕集終了の 1 分後 からフィル夕表面を IPに 10 分間密着させる。更にその直後, 密着位置をずらして 10 分間照射, この手続きを全 6 回繰り返す(合計 60 分間)。フィルタ上の核種の隇衰を回帰計算で解析すること により個別濃度を計算する。検出下限は平衡等価ラドン濃度で約 $20 \mathrm{Bqm}^{-3}$ となった。

$†$ 現所属 : 東京電力株式会社福島第二原子力発電所, 979-0695 福島県双葉郡楢葉町大字波倉字小 浜作 12 